\title{
THE POLISH-JeWISH LeTHAL POLKA DANCE
}

\author{
NITZA DAVIDOVITCH
}

Faculty of Social Studies, Ariel University, Ariel 40700, Israel

E-mail address: davidovitch.nitza@gmail.com

ORCID: https://orcid.org/0000-0001-7273-903x

\author{
EYAL LEWIN \\ Faculty of Social Studies, Ariel University, Ariel 40700, Israel \\ E-mail address: lewin1212@gmail.com \\ ORCID: https://orcid.org/0000-0001-5461-6634
}

\begin{abstract}
Aim. This paper analyses the inherent paradoxes of Jewish-Polish relations. It portrays the main beliefs that construct the contradicting narratives of the Holocaust, trying to weigh which of them is closer to the historic truth. It seeks for an answer to the question whether the Polish people were brothers-in-fate, victimized like the Jews by the Nazis, or if they were rather a hostile ethnic group.

Concept. First, the notion of Poland as a haven for Jews throughout history is conveyed. This historical review shows that the Polish people as a nation have always been most tolerant towards the Jews and that anti-Semitism has existed only on the margins of society. Next, the opposite account is brought, relying on literature that shows that one thousand years of Jewish residence in Poland were also a thousand years of constant friction, with continuous hatred towards the Jews. Consequently, different accounts of World War II are presented - one shows how the Polish people were the victims, and the others deal with Poles as by-standers and as perpetrators.

Results and conclusion. Inconsistency remains the strongest consistency of the relations between Jews and Poles. With the unresolved puzzle of whether the Polish people were victims, bystanders or perpetrators, this paper concludes with some comments on Israeli domestic political and educational attitudes towards Poland, that eventually influence collective concepts.

Cognitive value. The fact that the issue of the Israeli-Polish relationship has not been deeply inquired, seems to attest to the reluctance of both sides to deal with what seems to form an open wound. At the same time, the revival of Jewish culture in Poland shows that, today more than ever, the Polish people are reaching out to Israelis, and are willing to deal with history at an unprecedented level. As Israelis who wish to promote universal values, a significant encounter with the Polish people may constitute a door to acceptance and understanding of others. Such acceptance can only stem from mutual discourse and physical proximity between the two people.
\end{abstract}


Key words: Jewish-Polish relations, Israeli-Polish relations, Holocaust victims, bystanders, perpetrators

\section{INTRODUCTION}

Oap n February 1, 2018, despite Israeli and American criticism, Poland's Senate approved a highly controversial bill that bans any Holocaust accusations against Poles as well as descriptions of Nazi death camps as Polish. The law essentially bans accusations that some Poles were complicit in the Nazi crimes committed on Polish soil, including the Auschwitz-Birkenau extermination camp. Once the legislation was signed into law, about a fortnight later, by Polish President Andrzej Duda, anyone convicted under the law could face fines or up to three years in jail.

Critics of the bill, including the US State Department and Israeli officials, feared that it would infringe upon free speech and could even be used to target Holocaust survivors or historians. In Israel, the reaction was fierce. "One cannot change history, and the Holocaust cannot be denied," Israeli Prime Minister Benjamin Netanyahu stated. Israel's housing minister, Yoav Galant, condemned the bill after it was passed by Poland's Senate, tweeting that it constituted "Holocaust denial." Israel's Holocaust Remembrance Center similarly cautioned that the bill could blur the historical truths regarding the assistance the Germans received from the Polish population during the Holocaust.

"We are facing the biggest crisis in Polish-Jewish relations since 1989," said Agnieszka Markiewicz, director of the American Jewish Committee's central Europe office, referring to the year the Berlin Wall came down. "The way this conflict has escalated is horrible. There are things that have been said and done on both sides - including by Israeli politicians who said that there were Polish camps - which have not been helpful. Polish people do not bear responsibility for the Holocaust, as such. But like other nations, they do bear responsibility for the behaviour or attitudes of some."

Warsaw-based political scientist and advocate Rafał Pankowski said he had never experienced as much anti-Semitism in Polish public discourse as he did in the current discourse. "Anti-Semitism is not a new phenomenon here, but we are seeing an explosion of that sentiment in popular media mainstream [...]," Pankowski said.

Netanyahu and Polish Prime Minister Mateusz Morawiecki spoke by phone; however, in spite of the diplomatic dialogue, the Polish government stood by its bill and pursued Senate approval. The whole crisis, particularly the deteriorating relationship between Israel and Poland, should logically be puzzling. In light of the suffering of the Polish nation and the fate of Jews and non-Jews in Polish territory as a result of the Nazi occupation, it would seem that these nations would identify with each other and find common ground based on their painful past. Moreover, considering the large numbers of Israelis who visit Poland, it would be only natural for Poles and Israelis to form positive 
attitudes towards each other. No wonder that the two nations are in international political, economic, and cultural contact with each other. The number of Israelis visiting Poland rises each year, as does the number of Poles who visit Israel. Israeli businessmen invest in private industries in Poland, and Poles do business with Israelis. Israeli and Polish scientists visit each other and are cooperating more than ever before (Wróbel, 1997). Moreover, Jewish culture in Poland is enjoying a revival, with young Polish people in Krakow, Warsaw, Lublin, and Gdansk learning Yiddish, dancing the hora, eating chopped liver, and listening to Hassidic music (Horowitz, 2011).

On the other hand, one cannot deny that in practice, most Jews who come to Poland do so because of the historical context. While many Israelis travel to Germany as tourists, Israeli visits to Poland are almost always associated with the culture that was erased. Specifically, delegations coming to Poland primarily encounter historical Poland and memories of the Holocaust.

Is Poland to be considered an ally, a second homeland where Jews prospered for hundreds of years, or was it the hostile scene of generations of pogroms? Was Poland the paradise where Jewish life, religious as well as cultural, national particularistic as well as assimilationist, thrived, or was it a historical setup where a Jewish civilization would eventually be trapped to death? Were the Polish people brothers-in-fate, victimised like the Jews by the German conqueror, or were they a hostile ethnic group relieved by the Nazis who cleaned Poland of its Jews for them? Due to what historian Piotr Jan Wróbel (1997) called "the double memory," there is no simple answer, though in the following pages we shall try to search for one. The Polish-Jewish relationship has always been based on deep inconsistencies, and between Warsaw and Jerusalem, for over a thousand years now, it seems that in this sense - nothing much has changed.

\section{POLAND AS THE THOUSAND-YEAR-SHELTER FOR JEWS}

The Hebrew word for Poland is Polin [translation: "dwell here"]. Indeed, throughout much of Polish Jewish history, Jews have found in Poland a place to rest, to make their homes and to feel at home. Polish Jewish history is filled with extraordinary creativity and cultural achievement, and forms an ongoing story of intertwined narratives.

During the tenth and eleventh centuries, Jewish merchants and artisans settled in Poland. Persecuted and expelled from Western Europe, they found refuge and a haven under the Piast and Jagiellonian dynasties. When the first Polish coins were minted in 1206, some of them already bore Hebrew inscriptions, since the mint masters were Jews. Jews assumed positions in commercial and economic life, becoming merchants, money lenders, tax collectors and innkeepers. However, at the same time, Jews were segregated into Jewish quarters, were ordered to wear special emblems, and were banned from holding public offices higher than those held by Christians. Yet 
the restrictions seem to have proved ineffective, because they were repeated in subsequent years.

The kahal [Jewish institutionalized community] in Kalisz was first mentioned towards the end of the thirteenth century. The kahal collected taxes, supplied the Jews with communal services, enforced Jewish law and was responsible for the education and social welfare of its members. In 1334 King Kazimierz the Great broadened Jewish privileges. There is evidence that the king had a love affair with a Jewish woman named Esther, and whether true or not - the story would reverberate through Polish folklore through the ages. These were the years when waves of migration from Western Europe brought more Jews to Poland after the epidemics known as the Black Death for which the Jews were blamed in the West.

Until the sixteenth century, the number of Jews settling in today's Poland, Belarus, Lithuania, Ukraine and Russia increased, as Ashkenazi communities [those located along the Rhine in Germany] migrated to the east. They served the king, as well as members of the Polish aristocracy, as tax collectors, becoming merchants and innkeepers. They brought with them Jewish religious practices and political and commercial experience, as well as Yiddish - the German-based Hebrew-mixed dialect that would become for Jews the lingua franca and would later preserve the Jewish culture and heritage of Ashkenazi Jews in Eastern Europe.

In 1525 King Zygmunt I for the first time knighted a Jew, Michał Ezofowicz, without requiring conversion. Jewish converts to Catholicism, until the partitions of Poland, were usually granted noble status.

The Polish-Lithuanian Commonwealth was formed in 1569 and would last until 1795. It was also known as the Republic of the Two Nations, with a unified federal system and an elected monarchy, and became one of Europe's major political and cultural powers. Its first century is considered the Golden Age of Jewish life in Poland, often referred to as Paradisus Judaeorum [Jews' Paradise]. Granted relative autonomy, Jewish communities enjoyed economic growth and stability. Jewish culture thrived with the opening of Talmudic academies and centers of learning, as well as a proliferation of Jewish literature, secular and religious.

In the late sixteenth century an autonomous Polish Jewish ruling institution was formed, which would effectively act for almost two centuries: $V a^{\prime} a d$ Arba Ha-Aratzot [Council of the Four Lands]. The Council ruled over the Jewish communities of Greater Poland, Lesser Poland, Lithuania and Mazovia. Its primary function was to levy and collect taxes among Jewish communities. It was made up of delegates from the different Jewish communities, and it became the central body of Jewish self-government, recognized by the king - the only institution of its kind in the history of the Diaspora.

The Thirty Years War in the first half of the seventeenth century brought the last major wave of Jewish refugees from Western Europe to Polish lands. However, as soon as the war ended, Bogdan Chmielnicki, a Polish nobleman who rebelled against his country, led a Ukrainian Cossack uprising against 
Polish and Polonised gentry, Jesuits and Jews. Tens of thousands of Jews fell victim to the massacres; many were sold into slavery and later ransomed by a multinational effort of pidyon shouyim [redeeming the captives] among Jewish communities throughout the Four Lands and as far as Amsterdam. Jewish communities, in spite of being affected by loss of life and property, managed to re-establish themselves as quickly as possible; they fully recovered from the recent historic calamities, and Jewish cultural life was soon prosperous again throughout Poland.

In 1791 Poland became the first European country with a constitution. At the same time, Catherine the Great of Russia established the Pale of Settlement, restricting Jewish settlement in the Russian Empire. The Pale, the only region where Jews were allowed to reside, included eastern Poland and parts of present-day Latvia, Lithuania, Belarus, Ukraine and Moldova. In 1793 the second partition of the Commonwealth, by the Russian Empire and the Kingdom of Prussia, created new territorial divisions. In 1794 Many Jews joined Tadeusz Kościuszko, a veteran of the American Revolutionary War, in an insurrection against the Imperial Russian rule. Berek Joselewicz joined the Kościuszko Insurrection and formed a Jewish cavalry regiment, probably the first Jewish military unit in the history of the Diaspora. Later, as a colonel, he would lead another regiment during the Napoleonic wars and would die in battle against the Austrians.

By 1795, as a result of the third partition of Poland, the country was essentially erased from the map of Europe, and did not regain independence until the end of World War I. During the partition, the Polish population fell under the domination of one of the three empires: Russian, Prussian or Austrian. Polish Jewish families found themselves on different sides of the borders, serving in different armies, and integrating into different cultural traditions. However, Yiddish culture and increasing Jewish involvement in Polish society were some of the cohesive forces defining these communities. Hence, Jewish life under the partitions, in spite of the challenges and difficulties, continued to expand and develop.

In 1807 the constitution of the Duchy of Warsaw, a Polish state set up under Napoleon, granted Jews equal rights. In spite of the suspension of this ruling in 1808, it allowed Jews to integrate into the wider society. Jews living under Austrian rule were granted equal rights in 1861, under Prussian rule in 1869, and under Russian rule in 1917. Each regime required that Jews take on hereditary surnames for purposes of tax collection and the draft.

To a large extent, for better or worse, Jews fully supported - and in fact, often identified with - Polish nationalism. In 1830, during an unsuccessful uprising in the Kingdom of Poland against the Tsar, Jewish militias took part in the defense of Warsaw. This was a typical historic pattern, and in 1846 a failed uprising against Austrian rule in Kraków was supported by local Jews. In 1861, Jews in the Kingdom of Poland participated in the Polish national movement against Russian rule. Michał Landy, a rabbinical student in Warsaw, was killed by Cossack fire during a patriotic demonstration, having picked up a cross that 
a slain Catholic protester had been carrying. In 1863, during an uprising against Russian rule, Chief Rabbi of Warsaw Dov Ber Meisels, a political activist in the fight for Polish independence, was arrested and deported from Warsaw and moved, temporarily, to Kraków. Jews, one ought to mention, did not only participate in Poland's violent struggles for national independence, but were also part of its cultural aspirations. In the mid-1850s, Samuel Orgelbrand, a Warsaw-based printer and publisher, began to work on what would become the first modern Polish twenty-eight volume encyclopedia. Among many works published, Orgelbrand printed a twenty volume edition of the Babylonian Talmud; Polish nationalism and Jewish tradition presented for him and for so many others no contradiction.

When Poland regained independence in 1918, Józef Piłsudski, interim head of state, invited Jewish parties to participate in coalition talks. In 1919 The Jewish Delegates Committee represented Polish Jewry at the Versailles Peace Conference. The conference obliged newly independent countries, including Poland, to sign a treaty guaranteeing minority rights. That year, the first parliamentary elections gave seats to Jews in the Sejm and the Senate. Roza Pomerantz-Melzer, a member of a Zionist party, became the first woman elected to the Polish parliament. Jewish life and culture flourished unprecedentedly: schools, youth movements, sports clubs, theatre, cinema, literature, and the press all developed exponentially to meet the needs of the growing Jewish population and the diversity of Jewish expression.

In 1921, following a year of bitter war and a strategic Red Army defeat at the gates of Warsaw, the Polish-Soviet peace treaty was signed in Riga. Thousands of Jews, in particular shopkeepers and professionals forbidden to work in the Soviet Union, moved to Poland and were granted full citizenship, since the Polish constitution granted legal equality to all citizens. In addition to the formal legal protection of Jews against discrimination, in 1926 Piłsudski seized power in a coup and instituted a quasi-authoritarian regime. His opposition to anti-Semitism would now protect Jews and other minorities.

By the 1930s, the world Jewish population was estimated at 15 million, with 4 million in the United States, 3.5 million in Poland and 2.7 million in the Soviet Union. Jews constituted more than 10 percent of the population in Poland and provided 50 percent of all the lawyers, over 30 percent of all the doctors in Warsaw, and 25 percent of all the university students in Poland. After looking into a millennium of Jewish life in Poland, then, one has to agree that this country and its people generally embraced the Jews (Bergman et al., 2011; Lehrer, 2010; Rubinstein, 2015).

With such a historical review in mind, the Polish people have good reason to believe, as indeed most of them do, that as a nation they have always been most tolerant towards the Jews and that anti-Semitism has existed only on the margins of society. They contend that Poland served as a shelter for European Jews for centuries, when they were exiled from almost all other countries. Historically, then, Poland proved to be, for about a thousand years, a relatively 
safe haven for Jews, as Polish President Lech Walesa put it in his address to the Knesset Plenum in Jerusalem, during his visit on May 20, 1991:

Jews from all over the world would arrive in Poland. They found in our country hospitality and an atmosphere of tolerance. They found in our country a sense of security and the conditions to develop their great culture. Distinguished Jewish scientists and great spiritual leaders were active on Polish soil. Poland was home to both Poles and Jews.

However, in a sense, looking into Polish-Jewish history is like rotating a kaleidoscope and watching an eternally changing picture. Another glance at the same historical course of events might leave us with a totally different impression. (Aleksiun, 1999; Blatman, 2001; Zimmerman, 2003; Bergman et al., 2011; Lehrer, 2010; Rubinstein, 2015).

\section{POLAND AS THE CRADLE OF ANTI-SEMITISM}

One thousand years of Jewish residence in Poland were also a thousand years of constant friction, with hatred towards Jews orchestrating history's events. As early as 1267 The Catholic Council of Wrocław created segregated Jewish quarters. Jews were ordered to wear special emblems and were banned from holding public offices higher than those held by Christians. These measures were constantly repeated in subsequent years and in other locations in Poland.

The 1340s waves of Jewish migrations from Western Europe, following the Black Death epidemics, brought with them new allegations, blaming the Jews for the disease. Anti-Jewish riots were perpetrated in Silesia and later in Poznań and Kraków. A little more than a century later, in 1483, the Jews were expelled from Warsaw, and were permitted to live only outside the city limits. The expulsion order was repeated over and over again in subsequent years, for decades to come. In 1495 Jews were expelled from Kraków, the capital of the Polish Kingdom, as Kraków was granted the royal privilege de non tolerandis Judaeis [to not tolerate Jews].

In the midst of the so-called Jewish Golden Age in Poland, one ought to remember that tensions between the king and the nobility provoked instability. Embroiled in wars with Sweden, Russia and Turkey, the Commonwealth began to deteriorate. Growing poverty and discontent eventually gave rise to increasing anti-Semitism, and limitations on Jewish settlement within the Polish cities were renewed. The war with Sweden was followed by pogroms, with Jews accused of complicity with the enemy. Consequently, Jewish communities were shaken both by the ferocity of the attacks and the heavy loss of life and property, as well as by assaults by their Polish neighbors.

The Catholic Church added its portion of hatred with blood libels throughout the sixteenth century. In 1761 a provincial court ordered the burning of the Talmud, the last such event in Europe until the Third Reich's burning of books. 
It is true that Jews supported the Polish uprisings, hopeless and unsuccessful as they were, throughout the nineteenth century. However, when in 1848 a failed uprising against Prussian rule in Poznan was not supported by the Jews, they were subsequently accused of treason by the Poles.

In the 19th century, when the modern Polish nation was about to emerge, anti-Semitism was the ideological glue of great political nationalistic formations. Simultaneously, anti-Semitism in Poland was strengthened by the country's Russian occupiers in a divide-and-rule manner. In 1876 Jan Jeleński published "The Jews, the Germans and Us," the first manifesto of modern Polish anti-Semitism.

The failed 1905 revolution in Russia incited pogroms. A boycott of Jewish businesses, the first of its kind, was organised in Warsaw by Polish nationalists, when Jews refused to endorse their candidate.

It was not until 1918 that Poland became an independent state once again. During the turbulent years immediately following World War I, Jews were among the thousands who perished in pogroms instigated by Polish, Ukrainian and Russian civilians and military forces. In Lviv and in Vilna, both incorporated into newly-independent Poland, Jews often suffered at the hands of the Polish military. Additionally, the Jewish community all over Poland now suffered massive unemployment and a rising number of anti-Semitic incidents and pogroms; they also fell prey to the growing tension between a multicultural Poland and increasing nationalism.

During the 1920s and 1930s, anti-Semitism became a fixture among radical right-wing nationalists and was largely supported within the hierarchy of the Catholic Church. Jews began to be increasingly discriminated against and unsafe. With the rise of noisy anti-Semitic groups calling for pogroms, they were segregated at universities. Many Jews, therefore, claim that anti-Semitism was very common among the Polish people.

In 1920 many Polish Jewish army volunteers in the Polish-Soviet War were interned by Polish authorities as potentially untrustworthy. In 1923 various Polish universities introduced numerus clausus [quotas], limiting the number of places for Jewish students, based on their percentage of the population. In 1931 clashes in universities in Wilno (Vilna) and Lwów between the anti-Semitic National Democratic Party and Jewish students left one Polish student dead, as tensions and the imposition of quotas at universities increased. In 1937 "bench ghettos" [separate benches for Jewish students] were introduced in the majority of Polish universities. While academic segregation was opposed by the democrats and by members of academia, the right and others demanded the total exclusion of Jews from the universities.

In 1924, due to the restrictive economic policies of Prime Minister Władysław Grabski, thousands of Jewish businessmen, threatened by bankruptcy, were forced by economic conditions to leave Poland. In 1936 violent boycotts of Jewish businesses became commonplace, and Jews sometimes organised in self-defense. Boycotts and pogroms, sometimes with fatalities, occurred all over Poland in the late 1930s. In 1936 extremist leader Adam Doboszyński 
and his followers organised a March on Myślenice, occupying Warsaw, arresting local authorities, plundering Jewish shops, and attempting to set fire to the synagogue. Doboszyński was arrested and sentenced to three and a half years in jail. However, several months later the prime minister and Catholic Primate both endorsed an economic boycott of Jewish businesses and shops proclaimed by the extreme right, albeit condemning physical violence against Jews (Aleksiun, 1999; Blatman, 2001; Zimmerman, 2003; Bergman et al., 2011; Lehrer, 2010; Rubinstein, 2015).

The Jews were an ethnic community with a marked consciousness of their cultural distinctiveness, which had been strengthened through the centuries by their common history, and which manifested itself in the cult of tradition and religious ties. Apart from tradition and religion, other important factors binding the Jewish community were the Yiddish language, clothing, customs, and communal institutions. Poles and Jews, therefore, even when living in the same town, formed two separate environments. Hence, the model of bilateral contacts was at best one of peaceful isolation, of a life devoid of conflict, not necessarily one of mutual friendly feelings (Renz, 2004).

The seventh Israeli Prime Minister Yitzhak Shamir was born as Yitzhak Yezernitsky and raised in Poland, where his father was murdered by the local villagers who had been his childhood friends, and the rest of his family was killed in the Nazi death camps. Pointing out how the Poles were deeply imbued with hatred toward Jews, he asserted that they "suck anti-Semitism with their mother's milk" (JTA, May 10, 1989). Were Walesa's words right, then, and Poland was a refuge for Jews, or was it just another European environment of Jewish hatred, where a historical illusion would eventually turn into a national lethal trap?

\section{THE POLISH PEOPLE AS WORLD WAR II VICTIMS}

On September 1, 1939, Germany invaded Poland. For two weeks, Poland resisted the German army's Blitzkrieg, and 100000 Polish soldiers died before the Polish army collapsed, trapped between the Wehrmacht and the Soviet Red Army (Tzur, 1995). Even then, the Polish people continued to fight individually.

From the German point of view, the Poles, primarily those who belonged to the Roman Catholic Church, were untermenschen [subhuman], a group destined to serve the Aryan race - inferior slaves only slightly above the level of the Jews. The general idea of the Nazi occupation was to use Polish territory as the lebensraum [living space] for the Germans, and to turn Poles of Slavic descent into German servants and slaves. Elimination of the Polish nation was essential for this purpose.

During the war, the local Polish population suffered from the German occupation in several ways. Many were deported from areas intended for German residence and were forced to settle in the area of the General Administration. 
Hundreds of thousands were deported to Germany for forced labour in the weapons and agricultural industries, and many died there due to poor hygiene and nutrition. In all of Poland there was a general shortage of food, fuel for heating, and medication, and consequently mortality rates rose significantly. Thousands more died in cruel acts of retaliation initiated by the Germans for various reasons (Noakes and Pridham, 1990; Lukacs, 1989).

The German policy of occupation included various types of oppression and terror employed against the Polish people. The Germans created a rift within the population, by separating and dividing them into ethnic groups of different racial grades. The intellectual and financial elite was exterminated in order to prevent the possibility of organised resistance and to create circumstances in which the Germans need to handle only simple farmers with no leadership (Noakes and Pridham, 1990; Lukacs, 1989).

In 1939-1940 the Germans employed draconian means against the Poles. Citizens suspected of resistance to the Nazi occupation, or those marked by their social status as capable of resisting, were exterminated by the Einsatzgruppen. Tens of thousands of affluent landowners, entrepreneurs, doctors, teachers, and government officials were murdered or sent to concentration camps. As part of the destruction of Polish culture, the Germans closed or demolished universities, schools, museums, libraries, and laboratories. In order to prevent the emergence of a new intelligentsia, Poles were forbidden to study beyond elementary school. The Germans sought to create an illiterate, obedient population, incapable of resistance (Steinlauf, 1997).

In areas annexed to the Third Reich, the goal was to "Germanise" the geographical territory - Polish speaking elementary schools were closed, street names changed, Polish industries were nationalised, and Poles were forbidden from accessing public places. Over 325000 Poles were deported from the annexed territories to those of the General Administration, and all their possessions were confiscated. Some 50000 Polish children meeting Aryan standards were taken from their parents and forcibly given to childless Germans for adoption. As part of the oppression of the Polish population, Nazi authorities performed daily mass executions. Dozens of villages were completely annihilated. A total of 1.5 million Poles were taken to perform forced labour on behalf of the Third Reich. They were required to wear a purple patch on their clothes, marked with the letter " $\mathrm{P}$ ". They were forbidden to use public transportation and were subjected to a strict curfew. They were forbidden to have any social interaction with Germans after work. Sexual relations between Germans and Poles were considered a violation of racial purity and was punishable by death. A total of three million non-Jewish Poles died as a result of the German rule of Poland - 10 percent of the non-Jewish Polish population. Combined with the three million Polish Jews murdered, one in every five Poles died as a result of the German occupation (Noakes and Pridham, 1990; Lukacs, 1989).

The unique nature of the Nazi occupation resulted in disintegration of the foundations and values that held Polish society together. The disintegra- 
tion of Polish society, combined with the fact that the Poles were not only witnesses to the Nazi horrors but also their victims, who were exposed daily to senseless violence, created a situation in which ethics and values disappeared, and survival became a major goal. Considering the circumstances, the Polish people did the best they could to protect the Jews (Steinlauf, 1997; Zimmerman, 2003).

Alongside the Polish people's sufferings, one ought to remember that Poland was the first country to oppose Hitler's demands and the first to stand against his aggression. Unlike other European countries, Poland never had a Quisling. No Polish regiment fought on behalf of the Third Reich. Betrayed by the Ribbentrop-Molotov pact, Poles fought alongside the anti-Nazi forces from the first day until the last. And inside Poland, armed resistance to the German occupation was widespread throughout the war. British Prime Minister Winston Churchill praised the Poles for their role in the Battle of Britain and US President Franklin Roosevelt declared that the Polish people were an inspiration to the free world. However, all this respect towards them failed to prevent the leaders of the West from delivering Poland into Stalin's clutches at the 1945 Yalta Conference. Stabbed in the back, the heroes of the Polish resistance enemies of Stalin's Communism - ended up in Soviet gulags and Polish Communist prisons (Michnik, 2014). In this sense, the Polish people were not only Hitler's victims, but also the prey of the treacherous West.

Above all, Poland had the most citizens of any nation to receive the honour of Righteous among the Nations [the Israeli honorific for non-Jews who risked their lives during the Holocaust to save Jews]. It is true that Poland had the largest Jewish population in Europe during World War II; still, it must be pointed out that Poland also had the largest number of citizens executed for trying to help Jews - there were 704 documented cases altogether recorded by the Polish governmental Institute of National Memory, and perhaps more who may have been executed for the same reason. Furthermore, Poland was the only country in Eastern Europe that established an underground organisation with the specific purpose of rescuing Jews. Zegota, the codename for the Council to Aid the Jews, was initiated by writer Zofia Kossak-Szczucka. It included democratic Catholic activists, as well as both Jews and non-Jews from many different political movements. Despite their differences, they were motivated to fight the injustices perpetrated by the Nazis. Zegota furnished many Jews with false identification papers, money, and safe hiding places. Despite the death penalty imposed on people who hid Jews, Zegota members successfully placed thousands of Jewish children in foster homes, public orphanages, and convents. They also provided medical care to Jews in hiding. In Warsaw, for example, Irena Sendlerowa helped smuggle large numbers of Jewish children from the Warsaw Ghetto into safer hands, with the intention of returning the children to their parents after the war. In addition, Zegota tried very hard to persuade the Polish Government in Exile to implore the Polish people to help the Jews. Altogether, Zegota saved tens of thousands of Jews throughout the war (Paulsson, 2002). 


\section{THE POLISH PEOPle AS PERPETRATORS}

There is, however, vast disagreement concerning historical memories among scholars. Some even claim that the Polish narrative of the Holocaust is one of denial - particularly in light of the lack of symmetry between the fate of Jewish Poles, 90 percent of whom were annihilated versus non-Jewish Poles - with only 10 percent murdered (Michnic-Coren, 1999). A close look raises further uncertainty - in particular, the great question of whether the Polish people were victims, bystanders, or perpetrators.

One cannot ignore the fact that as early as the 1930s, right-wing led Poland turned toward Germany as a political ally to face the potential threat to the east of the Soviet Union, and began to adopt the Nazi model. As earlier conveyed, pogroms in Polish towns and villages took place increasingly, alongside riots at the universities. Propaganda campaigns against Jewish business were backed by legal discriminatory measures in all fields of life, and consequently - thousands of Polish Jews left for Holland, France, Belgium, and Palestine.

Some of the answers to the question as to whether Poland really belongs on the side of the victims of the Holocaust were given firsthand in the testimony of Calel Perechodnik. Perechodnik was a Polish Jew from Otwock - a small town near Warsaw whose eight thousand Jews were all murdered. In the vain hope of protecting himself and his family, Calel Perechodnik, a twenty-seven-year-old engineer of agronomy, decided to become a Ghetto policeman. The true tragedy of his choice became clear during an August 1942 aktion where he helplessly witnessed how his own wife and his two-year-old daughter were forced aboard a train bound for the Treblinka death camp. Perechodnik fled the Ghetto, found shelter with a Polish woman in Warsaw, and wrote his story in a diary. Shortly before his death in 1944, he entrusted the diary to a Polish friend, and the document was eventually given to the Yad Vashem Archives.

Perechodnik admitted that there were certainly Poles who willingly helped Jews, some of them unselfishly. In fact, he mentioned how the best proof of this was the fact that he was still alive to write his diary. However, he also pointed out how the lower classes of the townspeople as well as the peasants understood that they had an opportunity to enrich themselves, one that came only once in a great while. One could pillage without penalty, steal, kill people, so that many using the slogan "now or never" got to work. They raised their hands to heaven, thankful for the favour that they had lived to see such times. Consequently, in every town where there was an aktion, the ghetto was surrounded by a mob that participated in a formal hunt on Jews. Countless Jews perished at the hands of the Poles.

According to Perechodnik, simple Polish people considered themselves innocent. After all, the Germans were responsible. Whereas Jews did not even dream that the order to kill them would apply to all Jews, the Poles realised right away that no Jew would survive the war. When a Pole had a Jewish friend who gave him things for safekeeping, and the Jew was deported to Treblinka, the matter was finished. Possessions increased; the conscience was clear, and 
the disappearance of Polish Jews was now a fait accompli. Furthermore, inheriting from the deported Jews had a moral rationale: where did the Jews get such wealth from in the first place, if not from Polish soil? Thus, many Poles justified their stealth by claiming that the time had come for the Jews to repay their debt.

Things were worse, however, when a Jew appeared to be bothersome and wanted to live and remind his Polish compatriots of his possessions. There was no point in cooperating with such a Jew: he would not survive the war anyway, so he would never be able to repay the favour. He could never lodge charges before a court, never cast a shadow on an unblemished name. To give anything back to the Jew would simply be wrong, because doing so would invite others to come and claim back their property. When such Jewish claims were made, most often after a couple of months everything was back in order; the Jew perished and the matter was closed.

Not only the Polish simple people, but also the elite, and more so - the leadership, were responsible for the mental environment where Jewish blood became worthless. Even in the Independence Party's information bulletins that scorned German barbarism and expressed compassion for the Jews, it was clearly noted that the best class of Jews were those who before the war did not want to be a parasite on a foreign organism and left for Palestine. Moreover, the Polish armed forces held to their prewar anti-Semitism and had no intention of defending the Jews. Things would have been totally different if only there had been even one communique in the daily press, announcing how a Special Court had decreed a sentence of death on a functionary of the Blue Police for seizing and delivering Jews to the Germans. If only this had happened, various Polish policemen or private trackers were likely to stop their disgraceful practice. Unfortunately, the armed forces did not even proceed to enlist young and able Jews with the purpose of strengthening partisan detachments. Furnishing the Warsaw Ghetto fighters with arms would have exacted a price - and in any case, would have been too late to achieve anything other than honourable death (Perechodnik, 1996).

Perhaps one meaningful milestone in the debate as to whether the Polish people were doers or sufferers of atrocities throughout World War II is the forgotten - and then reemerging - story of Jedwabne, a small town in northeast Poland. The place received its first recognition from the Polish monarchy in 1736. Jews arrived in the town around the same time, and the town's handsome wooden synagogue dates from 1770. It is estimated that at the start of World War II, Jews made up between 60 and 70 percent of an overall population of about 2000. In the war's initial period, eastern Poland was occupied by the Soviet Union, under the terms of the German-Soviet boundary treaty. Despite an initial welcoming of Russian forces in the town, the Soviets terrorised the population and deported large numbers of its citizens to Siberia.

Soviet occupation of Jedwabne was followed by that of the Germans during the June 22, 1941, Nazi invasion of the USSR. A wave of anti-Jewish sentiment swept the region, due to the belief that Jews had cooperated with and bene- 
fited from the Soviet invaders. Less than three weeks after the arrival of the Germans, on July 10, the mayor of Jedwabne, Marian Karolak, and the German gendarmerie gave the order for the roundup of the town's Jews. These included both Jewish residents of Jedwabne and those from surrounding towns who had sought refuge there (Gross, 2001).

Anna Bikont was a ten-year-old Polish girl when on July 10, 1941 she watched how her townspeople drove their Jewish neighbours into a large barn. Schoolboys jeered at their Jewish classmates, hounding them toward death. Mothers wrapped their babies tight as they tried to shield them against the blows. Shortly, nearly all of Jedwabne's Jews, hundreds of them, from infants to old people-would be burned alive. Small Anna saw how the people poured gasoline at the barn's four corners and set it alight. Then came a scream that she would not forget for decades to come. Only sixty years later, Bikont, now a reporter for the Gazeta Wyborcza, the liberal Polish newspaper, interviewed witnesses, perpetrators, and survivors of the Jedwabne massacre and similar mass killings of Jews in the nearby towns of Radzilow and Wasosz. Bikont revealed how all of Jedwabne knew for years who the leading murderers were, who stayed home that day in July 1941 and who joined the bloodthirsty mob. These truths were passed down for decades in hints and whispers at kitchen tables and over rounds of vodka. What happened in 1941 was not a pogrom but genocide; it was Jedwabne's wholehearted effort to shatter every trace of Jewish life. Minutes after the killings the town went on a massive looting spree, robbing Jewish homes of silverware, furs, and furniture. These were their neighbours, people they had known for years (Bikont, 2016).

Bikont's book appeared in Polish in 2004, and years later was translated first into French and then into English. Later, historian Jan Tomasz Gross described, in another book, the long-repressed mass murder in chilling and carefully footnoted detail (Gross, 2001). Bikont and Gross laid open the dark side of Polish-Jewish relations, which had been covered up for a period of sixty years.

The mass murder in Jedwabne was not an isolated event. In the summer of 1941, after the Soviets had fled and Germans had entered Polish territory, the region of Łomża and Białystok saw numerous acts of violence perpetrated by Poles on their Jewish neighbours, with varied participation by the new occupant (Gross, 2001).

The IPN [Institute of National Remembrance - Commission for the Prosecution of Crimes against the Polish Nation] was established in December 1998 by the Polish Parliament. Its actual activity began in the middle of 2000, the moment the first President of the IPN was chosen by the Sejm. The IPN is a special institution having the functions of state and justice administration, an archive, an academic institute, and an education center. An investigation carried out by this institute showed that events like the Jedwabne massacre had unfolded in at least twenty-three other Polish localities, including Bielsk Podlaski, Choroszcz, Czyżew, Goniądz, Grajewo, Jasionówka, Jedwabne, Kleszczele, Knyszyn, Kolno, Kuźnica, Narewka, Piątnica, Radziłów, Rajgród, Sokoły, Stawiski, Suchowola, Szczuczyn, Trzcianne, Tykocin, Wasilków, Wąsosz, and Wizna. 
The acts in all of these mass murder sites had four common features: anti-Semitism existent in a significant part of the Polish population; looting of Jewish property as one of the main motives for aggression; seeking retribution for real or imagined cooperation of Jews with the Soviet occupant; German incitement - varying from place to place, from direct organisation of pogroms to encouraging or condoning the behavior.

\section{CONCLUSION}

Inconsistency remains the strongest consistency of the relations between Jews and Poles. During Hitler's occupation, the Polish nationalistic and antiSemitic right refused to collaborate with the Nazis, as the right wing did elsewhere in Europe; Polish anti-Semites fought against Hitler, and some of them even rescued Jews, though this was punishable by death. Thus we have a singularly Polish paradox: on occupied Polish soil, a person could be an anti-Semite, a hero of the resistance, and a saviour of Jews (Michnik, 2014).

With Poland abandoned on the wrong side of the iron curtain, Stalinist terror blocked any public discussion in that country about the war, the Holocaust and anti-Semitism (Michnik, 2014). Deserted in the misery of the Soviet occupation, locked during the Cold War in the Warsaw Pact, the Polish history of resistance and fighting throughout World War II was now somewhat cut out of the Western narrative of war valour. This immediately damaged Poland's international public image as one of the war's heroes. To give just one example, a country like The Netherlands won thousands of awards for its Righteous among the Nations throughout the 1950s and 1960s, portraying the Dutch people as the Jews' best friends on earth; the Polish leadership, on the other hand, totally detached from the West, did nothing to promote any documentation of Polish rescuers of Jews until as late as the 1990s (Gerstenfeld, 2000).

Domestic politics in Israel, the post-World War II spiritual center of the Jewish world, made things even worse. Israeli Right-Wing pre-state underground organisations were disdained by the Zionist Socialist leadership that controlled collective memory during Israel's formative decades. Accordingly, the Armia Krajowa, the dominant Polish resistance movement that was active throughout the whole war, was shunned, whereas the equivalent leftist organisation, the smaller Armia Ludowa, created as late as January 1944, became the only Polish partisan group to be mentioned in Israeli history books. The fabricated dichotomy between Right Polish anti-Semites and Leftist Polish antiNazis served the internal whirlpools of Israeli politics, but made it difficult to understand the complexities of Polish reality (Lewin, 2014).

Davidovitch and Soen (2015) studied the Israeli youth delegations to Poland, where almost 33 percent of Israeli teens visit, during eight intensive days, the remnants of concentration camps, death pits, Jewish cemeteries and empty synagogues, relics of shtetls and traces of the Warsaw Ghetto. The object of this trip is that through experiential learning the school kids receive a close 
view of the history of the Jewish people, the diverse culture destroyed, and the beastly cruelty of the Nazi enemy.

In order to comprehend the views of participating teens and their attitudes towards the Polish people, the attitudes of 1108 high school participants in various delegations were tested. The findings show that 29 percent have a firm opinion that most of the Polish people acted against the Jews during the Holocaust and collaborated with the Nazis; and 23 percent hold the opinion that most current-day Poles are anti-Semitic. In contrast, only 19 percent of respondents declared that their attitude toward Polish people is positive. These findings prove that the Poles are not necessarily wrong to claim that Israelis bear them a grudge for past events. It seems that analysis of the delegations' participants shows a negative attitude towards the Polish people, at least among a large segment of the sample. It would be no exaggeration to say that for a large number of Israelis Poland is merely a cemetery - a memorial to that which was and is no longer.

The fact that the issue of the Israeli-Polish relationship has not been dealt with as part of the delegations project seems to attest to the reluctance of both sides to deal with this open wound. At the same time, the revival of Jewish culture in Poland (Horowitz, 2011) shows that, today more than ever, the Polish people are reaching out to Israelis, and are willing to deal with history at an unprecedented level. As Israelis who wish to promote universal values, a significant encounter with the Polish people may constitute a door to acceptance and understanding of others. Such acceptance can only stem from mutual discourse and physical proximity between the two peoples (Davidovitch and Soen, 2015).

\section{REFERENCES}

1. Aleksiun, N. (1999). Polish Historiography and the Jewish Holocaust. Bishvil Hazikaron, 34, 34-42 [Hebrew].

2. Ben Arieh, K. (1987). September 1939. Tel Aviv: Lavi [Hebrew].

3. Bergman, E., K. Czerwonogora, K. Gebert, V. Hannush, H. Lieberman, M. Matuszewka, \& Sajdak, A. (2011). 1000 Years of Jewish Life in Poland. Belmont, CA: Taube Foundation for Jewish Life and Culture.

4. Bikont, A. (2016). The Crime and the Silence: Confronting the Massacre of Jews in Wartime Jedwabne. New York, NY: Farrar, Straus and Giroux.

5. Blatman, D. (2001). Polish Self Examination and the Jewish Perspective. Bishvil Hazikaron, 43, 12-16 [Hebrew].

6. Davidovitch, N., \& Soen, D. (2015). The Trip Experience - Poland and the Polish People as Perceived by Israeli Youth in Light of their Trips to the Death Camps. In N. Davidovitch, \& D. Soen (Eds.). (2015). Shoa and Experience - A Journey in Time. Boston, MA: Academic Studies Press.

7. Gerstenfeld, M. (2000). Wartime and Postwar Dutch Attitudes toward the Jews: Myth and Truth. Jewish Political Studies Review, 12 (1, 2), 55-95.

8. Gross, J. T. (2001). Neighbors: The Destruction of the Jewish Community in Jedwabne, Poland. Princeton, NJ: Princeton University Press.

9. Horowitz, G. (2011). The Other Poland. Yisrael Hayom, November 27, 2011: 5. [Hebrew].

10. Lehrer, E. (2010). Can There Be a Conciliatory Heritage? International Journal of Heritage Studies, $16,269-288$.

11. Lewin, E. (2014). Ethos Clash in Israeli Society. Lanham, MD: Lexington. 
12. Lukacs, R. C. (1989). Out of the Inferno: Poles Remember the Holocaust. Lexington, KY: University Press of Kentucky.

13. Michnic-Coren, J. (1999). The Troubling Past: The Polish Collective Memory of the Holocaust. European Bibliography of Slavic and East European Studies, 29, (1-2), 75-84.

14. Michnik, A. (2014). The Trouble with History: Morality, Revolution and Counterrevolution. New Haven, CT: Yale University Press.

15. Noakes, J. and G. Pridham (1990). Nazism: A History in Documents and Eyewitness Accounts, 1919-1945. New York, NY: Schocken Books.

16. Paulsson, G. S. (2002). Secret City: The Hidden Jews of Warsaw, 1940-1945. Suffolk, UK: Yale University Press.

17. Perechodnik, C. (1996). Am I a Murderer? Testament of a Jewish Ghetto Policeman. New York, NY: Westview Press.

18. Renz, R. (2004). Small Towns in Inter-War Poland. In A. Polonsky (ed.) (2004). Polin: Studies in Polish Jewry. (pp. 143-151). Portland, OR: Litman Library of Jewish Civilization.

19. Rubinstein, E. (2015). Witness: Passing the Torch of Holocaust Memory to New Generations. Toronto, Canada: Second Story Press and March of the Living.

20. Steinlauf, M. C. (1997). Bondage to the Dead: Poland and the Memory of the Holocaust. New York, NY: Syracuse University Press.

21. Wróbel, P. (1997). Double Memory: Poles and Jews after the Holocaust. East European Politics and Societies, 11, 560-574.

22. Zimmerman, J. (2003). Contested Memories: Poles and Jews during the Holocaust and its Aftermath. New Brunswick, NJ: Rutgers University Press. 